\title{
Essential Managerial Skills for Brazilian Micro and Small Business Managers
}

\author{
Fernando Hungaro Lemes Gonçalves ${ }^{1}$, Rosana Cláudia Smék Batista ${ }^{1}$, Vanessa Piffer ${ }^{1}$, Artur Aguiar de \\ Albuquerque $^{2} \&$ Fábio Rogério de Morais ${ }^{1}$ \\ ${ }^{1}$ Business and Management Department, Rondônia Federal University, Rondônia, Brazil \\ ${ }^{2}$ Business and Management Department, Indiana Institute of Technology, Indiana, USA \\ Correspondence: Fábio Rogério de Morais, Business And Management Department, Rondônia Federal University, \\ Rondônia, Brazil.
}

Received: April 21, 2020

doi:10.5430/ijba.v11n3p60
Accepted: May 11, 2020

Online Published: May 14, 2020

URL: https://doi.org/10.5430/ijba.v11n3p60

\begin{abstract}
The objective of this research was to identify which are the managerial competences perceived as essential by the managers of micro and small active companies, located in the city of Porto Velho, State of Rondônia - Brazil. The relevance of the research is located in the managerial field, as a context of micro and small companies in developing regions, and, besides that, there is a theoretical expansion in the identification of managerial competencies essential to the management of micro and small companies in countries in economic and social development. The research model is the quantitative method, applied to a sample of 347 micro and small entrepreneurs from the universe of 10,221 companies, with sampling for convenience and accessibility, and data collected using a Likert scale. Therefore, the research identifies the factors that make up managerial skills, such as the dimensions "focus, production and development", which encompasses the vision focused on the interior of the company and at work; "planning and control", with an emphasis on plans and their execution, especially on the necessary resources; "market differentiation", with a focus on high competition and consumers; and, finally, "training and investments", which focuses on investments in labor and the acquisition of financial resources for the organization. These four factors synthesize the grouping of managerial skills essential for the management of micro and small companies, according to the perception of the managers participating in the sample, and, if applied to the management of micro and small companies, positively impact the survival of small businesses located in developing geographic regions.
\end{abstract}

Keywords: managerial competences, entrepreneurs, managers, micro and small companies, Brazil

\section{Introduction}

Entrepreneurship is decisive for the economic development of countries and regions, as it promotes improvements in markets, technologies, employability and people's quality of life. However, the relationship between entrepreneurship and economic development is not always consistent, as there are ambiguities in terms of balance in management, policies and economics, as a consequence of differences in market contexts (segment/scenarios), in types of motivation for entrepreneurship (opportunity/need) and entrepreneurial characteristics (professional/experimental) (Barbosa, Silva, Gonçalves \& Morais, 2020; Kummitha, 2019; Mwobobia, 2012; Toma, Grigore \& Marinescu, 2014).

In Brazil, entrepreneurs of Micro and Small Companies (MSCs) face great challenges, such as the high tax burden, the lack of specific tax and legal incentives for this segment, the difficulty of competing with large corporations, logistics problems, lack of knowledge of the field, rapid changes in consumer behavior, among others. In addition, the entrepreneur is often the creator, owner, manager and executor of small businesses, which makes his job as a manager more complex, as there are many elements of the business that demand his attention and take his focus away from management (Araújo, Morais \& Pandolfi, 2019).

In this context, although the manager of a small business has a range of management tools at his/her disposal, he/she does not always have the knowledge and access to the tools produced by the management area, whose purpose is to help entrepreneurs and managers to overcome day-to-day management challenges (Maldonado-Guzman, Marin-Aguilar \& Pinzon-Castro, 2017; Mwobobia, 2012). Another important issue when analyzing entrepreneurship 
is that the management area has studied the causes and the main characteristics of entrepreneurship in human beings, but there is still room for a discussion on the managerial competencies essential to the management of MSCs, in the entrepreneurship literature (Albuquerque, Gonçalves Júnior, Lacerda, \& Morais, 2019; Barbosa, Silva, Gonçalves \& Morais, 2020; Kummitha, 2019; Toma, Grigore \& Marinescu, 2014).

It is identified in the literature of the management area that it is necessary for the entrepreneur and/or the manager of micro and small companies some qualities, presented by the theory as management competences. Managerial skills are intended to promote the healthy development of organizations and not allow them to appear in business mortality statistics (Araújo, Morais \& Pandolfi, 2019). It is observed that managerial competences form the list of knowledge, skills and attitudes necessary for the good management of a business, and, when combined, give management the necessary conditions to overcome obstacles, motivate the team, develop the organization's capabilities and promote business success, whether they are essential or complementary management skills (Lara \& Salas-Vallina, 2017; Hamel \& Prahalad, 1990; Maldonado-Guzman, Marin-Aguilar \& Pinzon-Castro, 2017; Quinn, Faerman, Thompson \& McGrath, 2003; Walter, Auer \& Ritter, 2006).

In this scenario, it is important to understand the roles played by managers and which competencies are essential to the management of micro and small companies, as previous studies have identified that deficiencies in management skills can cause corporate mortality (Albuquerque et al. 2019; Araújo, Morais \& Pandolfi, 2019; Eniola \& Entebang, 2015; Ferreira et al., 2012). In the Brazilian context, it is highlighted that micro and small companies are important for the generation of jobs and income, economic growth and social inclusion, because they represent $98.2 \%$ of the companies installed in the national territory and $51.2 \%$ of the hand workforce with formal work; moreover, they are the main generators of wealth in almost all sectors of the economy, corresponding to $53.4 \%$ of the Gross Domestic Product (GDP) of commerce (market) and $22.5 \%$ of industry, in addition, it participates in one third of the production of services in Brazil (SEBRAE, 2016).

Although MSCs are of great importance for the Brazilian national economy, it appears that there is a high percentage of failure by these companies. The southeastern region of Brazil has the highest survival rates for companies with up to two years of activity: industry has $82 \%$, commerce has $78 \%$, civil construction has $81 \%$, services have $76 \%$, and, when considered as a whole, there is the highest survival total, with an average rate of $78 \%$; the region where the survey was applied has the worst business survival indicators and has the lowest survival rates for the civil construction sectors, with $69 \%$, and services, with $74 \%$; when considered as a whole, it has the lowest business survival rates in the first two years, with $25 \%$ mortality (SEBRAE, 2016).

In this scenario, it is relevant to understand what are the dimensions that make up the managerial competencies necessary for the management of micro and small companies, because, with this, mechanisms can be developed to minimize the death of this type of organization, especially those located in areas/regions with a high density of corporate mortality. In this theoretical-empirical discussion, the present research seeks to answer the following research problem: what are essential managerial competencies for the management of micro and small companies located in regions with high density of business mortality? To answer this research question, the study aims to identify which are the managerial competencies perceived as essential by managers of micro and small companies in the city of Porto Velho, State of Rondônia, Brazil.

\subsection{Models of Managerial Competencies}

The models of managerial competencies reflect the actions and behaviors adopted by individuals in the management activity and are constantly evolving. Table 1 shows the main elements that make up the four models used by this study to identify the managerial skills essential to the management of micro and small companies. 
Table 1. Main theoretical contributions to the study of managerial skills

\begin{tabular}{|c|c|c|}
\hline Model & Main Management Function & Main Management Capacities \\
\hline $\begin{array}{l}\text { Rational } \\
\text { Goals } \\
\text { Model }\end{array}$ & $\begin{array}{l}\text { The role of the manager is to be a decisive } \\
\text { director and a pragmatic producer. }\end{array}$ & $\begin{array}{l}\text { - Labor productivity; } \\
\text { - Promotion of a productive work environment; } \\
\text { - Time and stress management; } \\
\text { - Development and communication of a vision; } \\
\text { - Establishment of goals and objectives; and } \\
\text { - Planning and organization. }\end{array}$ \\
\hline $\begin{array}{l}\text { Internal } \\
\text { Processe } \\
\text { s Model }\end{array}$ & $\begin{array}{l}\text { The role of the manager is to be a technically } \\
\text { competent monitor and a reliable coordinator. }\end{array}$ & $\begin{array}{l}\text { - Monitoring of individual performance; } \\
\text { - Performance management and collective processes; } \\
\text { - Analysis of information with critical thinking; } \\
\text { - Project management; } \\
\text { - Work planning; and } \\
\text { - Multidisciplinary management. }\end{array}$ \\
\hline
\end{tabular}

Human The role of the manager is to assume the role of
Relation empathic mentor and process-centered
s Model facilitator.

- Team building;

- Use of a participatory decision-making process;

- Conflict management;

- Understanding yourself and others;

- Effective communication; and

- Employee development.

\begin{tabular}{ll}
\hline & \\
Open & The manager is expected to be a creative \\
Systems & $\begin{array}{l}\text { innovator and a negotiator endowed with } \\
\text { Model }\end{array}$ \\
& $\begin{array}{l}\text { substantial political cunning (someone who uses } \\
\text { the power and influence in the organization). }\end{array}$
\end{tabular}

- Living with change;

- Creative thinking;

- Change management;

- Constitution and maintenance of a power base;

- Negotiation of agreements and commitments; and

- Presentation of ideas.

Source: Adapted from Quinn et. al. (2003)

In these four models, it is possible and desirable that managers have a good performance in different dimensions of managerial competencies, so that they can perform their functions well and obtain good results, given that these are invisible values for which projects, programs and organizations maintain themselves whether active or not. Each model directs competencies to different benefits and strategies, sometimes even antagonistic. However, to expand thinking and increase the possibilities of choice and effectiveness in an organization, the manager must appreciate the advantages and disadvantages of each of the four models, acquire and use the skills associated with them and integrate the skills of each model to the situations day-to-day management (Quinn et al., 2003).

Hamel and Prahalad (1990) address the importance of competency development in organizations as a determining factor for success and argue that it sets them apart from others - i.e., expertise in a specific area or mastery of certain techniques can be differentials for success. Thus, the concept of competence can be analyzed from the perspective of the organization, with an emphasis on the conceptual aspects of the company, and from the perspective of people, with an emphasis on training and human development. In this study, we approach managerial competence from a human perspective, in particular the competencies needed by managers, such as observed or potential behaviors, 
through which managers demonstrate knowledge, skills, attitudes or synergy between personal competencies, as attributes seen as a result positive for yourself, teams, organizations or business networks, in a way compatible with the context, the available resources and the strategy adopted (Freitas \& Odelius, 2017). Thus, Quinn et al. (2003) present the concept of essential competencies to managers, where identify the models of managerial competencies needed by managers, as shown below in Table 2 .

Table 2. The eight roles of managerial leadership and their respective key competencies

\begin{tabular}{|c|c|c|}
\hline Models & Roles & Competencies \\
\hline \multirow[t]{6}{*}{ Model of Internal Processes } & \multirow[t]{3}{*}{ Monitor } & Monitoring Individual Performance \\
\hline & & Performance Management And Collective Processes \\
\hline & & Critical Thinking Information Analysis \\
\hline & \multirow{3}{*}{ Coordinator } & Project Management \\
\hline & & Work Planning \\
\hline & & Multidisciplinary Management \\
\hline \multirow[t]{6}{*}{ Model of Human Relations } & \multirow[t]{3}{*}{ Facilitator } & Team Building \\
\hline & & Use of a Participatory Decision-Making Process \\
\hline & & Conflict Management \\
\hline & \multirow{3}{*}{ Mentor } & Understanding Yourself And Others \\
\hline & & Effective Communication \\
\hline & & Employee Development \\
\hline \multirow[t]{6}{*}{ Model of Open Systems } & \multirow[t]{3}{*}{ Innovator } & Living With Change \\
\hline & & Creative Thinking \\
\hline & & Change Management \\
\hline & \multirow[t]{3}{*}{ Negotiator } & Constitution and Maintenance of a Power Base \\
\hline & & Negotiation of Agreements and Commitments \\
\hline & & Presentation of Ideas \\
\hline \multirow[t]{6}{*}{ Rational Goals Model } & \multirow{3}{*}{ Producer } & Labor Productivity \\
\hline & & Promotion of a Productive Work Environment \\
\hline & & Time and Stress Management \\
\hline & \multirow[t]{3}{*}{ Director } & Development and Communication of A Vision \\
\hline & & Establishment of Goals And Objectives \\
\hline & & d Organization \\
\hline
\end{tabular}

Source: Adapted from Quinn et. al. (2003)

According to Morais and Luz (2015), this model of managerial competences proposed by Quinn et. al. (2003) may present variations in intensity and use in the type of skills or group of skills according to the type of business or organization. Thus, according to the manager's competence or skills needs, more emphasis can be placed on the grouping of competencies in the sphere of the internal processes model, in the human relations model, in the open 3 systems model and in the rational goals model (Quinn et al. 2003). Therefore, it is based on this model of competences that one seeks to identify the essential managerial competencies for managers of micro and small companies. 


\section{Method}

To identify whether the managerial skills presented by Quinn et. al. (2003) are necessary and sufficient for the management of micro and small companies, it is essential to know which ones are considered essential and if they can be grouped as indispensable for the management of micro and small businesses, in the view of managers who use them in this type of companies. For this, it carried out a quantitative, explanatory, cross-sectional survey, applied to a sample of 347 micro or small entrepreneurs in the city of Porto Velho, Capital of the State of Rondônia, Brazil, which comprises the universe of 10,221 companies, according to IBGE (the Brazilian Institute of Geography and Statistics) (2017). The sample was extracted for convenience and accessibility, using a five point "Likert scale" data collection instrument (Malhotra, 2012; Saunders, Lewis \& Thornhill, 2012; Hair Jr. et al., 2014).

It is important to note that the sample universe of 10,221 companies, as presented in the IBGE report (2017), is the total number of companies in the city of Porto Velho, as there is no specific extract from micro and small companies. Thus, the sample of 347 units was calculated according to research practices in the area of Applied Social Sciences, with 95\% confidence (Malhotra, 2012; Hair Jr. et al., 2014). To collect the data, the questionnaire with interval scale was applied, built based on the managerial competences model proposed by Quinn et. al. (2003), and scale already validated (Felício, Parreira \& Lopes, 2011), in addition to information from the SEBRAE report (2016) on the causes of corporate mortality due to the absence of managerial skills. The sample calculation considered the positive range of $\mathrm{p}=0.50$, which is the value used when the proportion of the attribute in the population is not known, for a $5 \%$ error and a 95\% confidence level, which rounds off the value obtained for the next whole number (Malhotra, 2012; Hair Jr. et al., 2014).

The data collection instrument used for this research was composed of three (03) socioeconomic questions, two (02) questions related to the size of the company and activity segment, twenty-four (24) statements elaborated from the managerial competencies model proposed by Quinn et. al. (2003), with three (03) statements for each competency, and eight (08) statements elaborated on the factors causing business death, with two (02) statements each, which represents the four (04) factors of business mortality present in the Brazil.

\subsection{Validity of the Data Collection Instrument}

In order to analyze the reliability of the research instrument, Cronbach's alpha coefficient was used, which presented the value of 0.894 , so the result is considered satisfactory and sufficient to guarantee the reliability of the research instrument, which indicates that the questions used are consistent with the information they want to measure. For the treatment of the data, univariate and multivariate data statistics methods were applied with descriptive statistics, cluster analysis and factor analysis (Malhotra, 2012; Hair Jr. et al., 2014).

\section{Results}

The results are organized into topics, as described below are descriptive statistics, cluster analysis and factor analysis.

\subsection{Descriptive Statistics}

Most of the managers surveyed (41\%) are aged between 26 and 39 years old and the smallest part (3\%), are over 65 years old. When we started the research, it was expected that the managers of the companies surveyed would have older age levels, (i. e.) older people occupy the management positions in greater numbers. However, the results showed the tendency of Brazilian entrepreneurship in micro and small companies (Galvan \& Villela, 2014), where, after some time in the company's management, the manager also starts to undertake in his/her own business, often in competition with the company where he/she was a manager. And the second discussion is about the manager's role, presented by Davel and Melo (2005), where they report results of research that highlight high levels of stress and discontent on the part of managers in the execution of their functions, due to the demands of time and dedication, which can influence the departure of managers with more time in the job. 


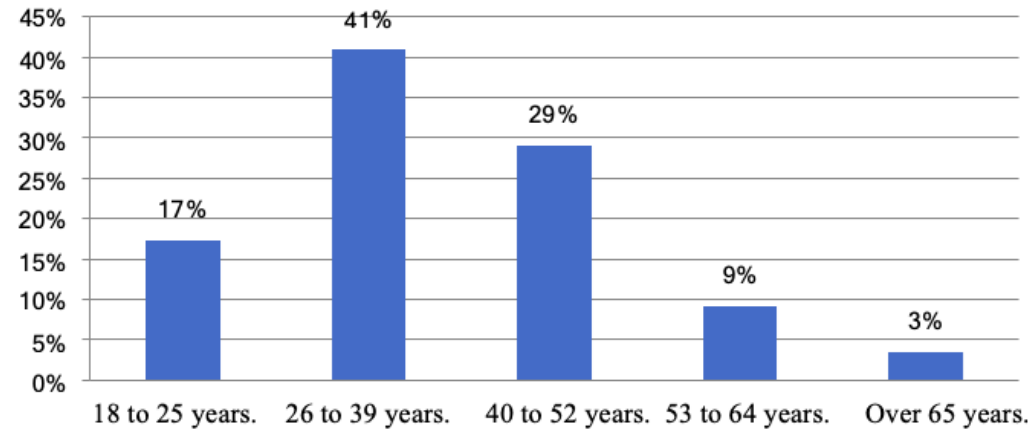

Figure 1. Graph with the age group of the respondents

Source: Research data

Thus, the empirical data are convergent with the Brazilian theory, since less than $50 \%$ of managers are over 40 years old, regardless of the reasons, whether due to the fact that older managers seek to invest in their own business or leave the position for reasons of stress and discontent with functional activities.

Regarding the education of the professionals surveyed, more than half (55\%) have completed high school and 25\% have completed higher education. This is a positive indicator for the northern region of Brazil, as the indices presented by IBGE (2018) inform that the illiteracy rate in this region is $8.0 \%$ of the population, while $41.2 \%$ of the population complete only basic education, and only $8.3 \%$ of the population was in higher education, in the period surveyed. It can be said that the results presented exceed the expectations of the research, considering the low level of supply of qualified labor in the region where the research was applied.

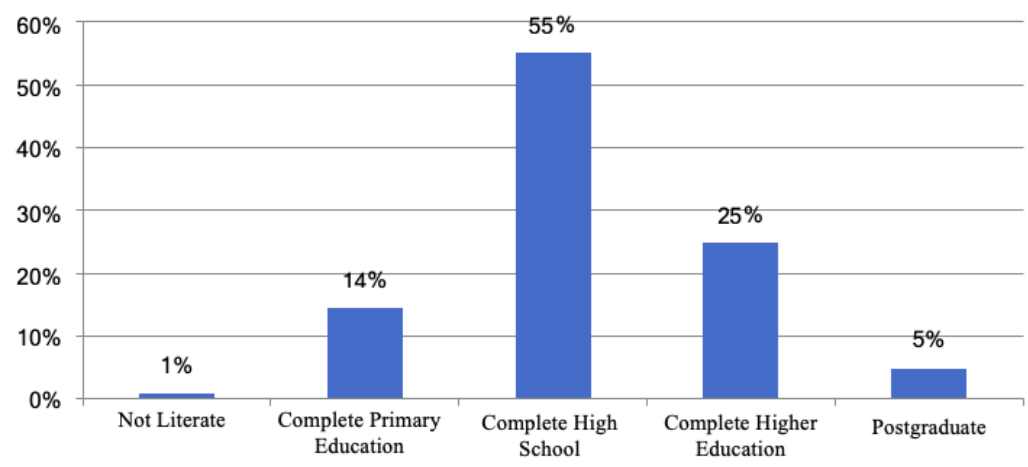

Figure 2. Graph with the educational level of the respondents

Source: Research data

The results indicate that the managerial competence related to the search for educational improvement is important for the managerial activity and, in this sample, the managers are under development, mainly, in the high school and higher education levels. It is possible to infer that the companies in the sample choose managers with a higher educational level and more qualified managers. As for the time working as a manager, as well as the time in the organization surveyed, the results show that the majority $(76 \%)$ of the respondents have total professional experience over five years, and, within this group, $51 \%$ of managers exercise the function for more than five years and $47 \%$ of them have worked in the same company for more than five years. 


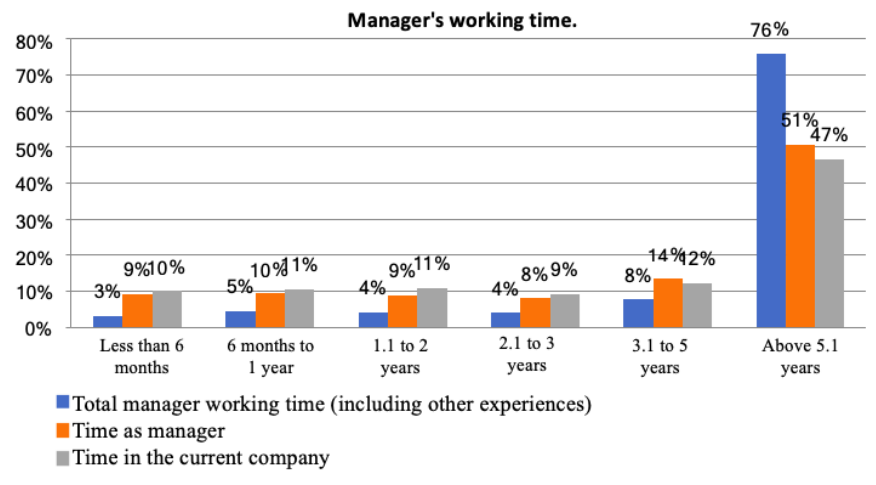

Figure 3. Graph with the working time of the researched manager

Source: Research data

It was identified that the majority of managers are stable in the company who have low professional turnover in the position of manager. The data also indicate that there was little hiring or movement of professionals over time in the role of manager, when considering the difference in the number of professionals in the ranges between "above 5.1 years" and "between 3.1 and 5 years ". It is possible to infer that the companies reduced the allocation of professionals in the manager position during the period after 2015, as the rates are stable in the periods between "less than 06 months" and "from 3.1 to 5 years", with an average result approximately $10 \%$ of movement in the first five periods, increased to $51 \%$ in the last quadrant. It is still possible to infer that companies tend to allocate, in the position of manager, more experienced professionals with longer professional activity, given the significant differences observed between the total time of professional experience, where $76 \%$ of the interviewees have more than five years total professional experience, and the time of activity as a manager, where $51 \%$ have the same period of activity.

\subsection{Cluster Analysis}

In order to identify the formation of clusters or groups among the observed results, a map of clusters was generated, using the statistical software IBM SPSS V.24. In this map of clusters, it was possible to identify that the elements present in the statements of the SEBRAE report (2016) on business performance were represented by a group, while the managerial skills presented by Quinn et. al. (2003) were presented in another group, with a great difference in the correlation between one group and another. The fact that these two groups show significant differences between them is positive, as it represents the two dimensions studied in this work and serves as confirmation of the capacity of the data collection instrument.

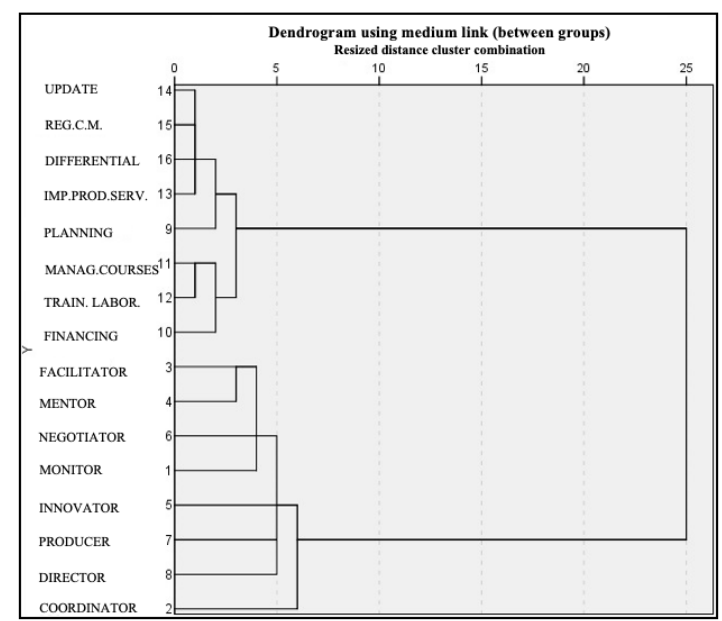

Figure 4. Cluster analysis

Source: Research data 
The components of the first group were: update with the market; registration of cash movements; differential in relation to the competition; improvement of products and services; strategic planning; participation in management courses; training of labor; loans and financing. These are the items presented by SEBRAE (2016) as fundamental for the good performance of companies and, in the absence of them, the chances of business mortality are increased. This group has a strong correlation between items and small groups with a stronger correlation within the group itself, among them, the relationships between "updating with the market", "recording of cash movements" and "improving products and services" stand out. The strong correlation means that most of the interviewees showed greater concern about being up to date in the market in which they operate, they also showed concern about the need to carry out a correct record of cash movements and to improve their products and services. In the same way, we can observe a strong relationship between "differential in relation to the competition" and "strategic business planning". This correlation was expected, since companies that seek to differentiate themselves from others in the market, seek to differentiate themselves through strategic planning.

Still on the first group of formation in the cluster, there is a high correlation between "participation in management courses" and "training of labor", therefore, it is possible to observe that managers who are concerned with participating in courses for their training, also are concerned with providing training for their employees. This is a positive result, as it demonstrates that managers who understand the need to invest in their professional training also have the ability to perceive this need in their employees.

In the last of the isolated clusters in the first group, there is a strong correlation between "participation in management courses" and "acquisition of loans and financing", which can be explained by SEBRAE data (2016), which state that the manager has fear of acquiring loans and financing, due to uncertainties regarding the future capacity to pay obligations. However, the cluster data reveals that the most capable managers feel more secure in taking risks, since they are prepared to use resources efficiently and guarantee the ability to pay obligations, they are also able to visualize the potential for improvements that borrowing and financing can provide the business.

It was observed that the managerial skills described by Quinn et. al. (2003) were grouped in the second cluster: facilitator; mentor; negotiator; monitor; innovative; producer; director and coordinator. Like the first, this group has subgroups, or small clusters, within the group itself. The items that have the highest correlation are the skills of "facilitator" and "mentor". It is possible to note that, in the universe surveyed, the respondents who most identify with the competence of facilitator, also identify with the competence of mentor. This means that managers who see themselves as facilitators of situations and opportunities in their company, also see themselves as mentors to their employees, who directs these employees to opportunities. Still within the second group, it is possible to see a strong relationship between the skills of "facilitator" and "monitor", which means that the manager who considers $\mathrm{him} / \mathrm{h}$ erself a facilitator, in most cases also considers him/herself a monitor, that is, accompanies the activities and the progress of the tasks of his/her collaborators, composing the facilitator, mentor and monitor triad.

Among the relationships observed in the second group, it is possible to highlight the link between the roles of "negotiator", "producer" and "director", in which respondents who consider themselves negotiators, who seek to maintain a power base and, at the same time, have communication skills, also consider themselves productive, good administrators of time and tasks, organized, meeting goals and objectives, in addition to being able to transmit this vision to their subordinates.

In the last cluster within the second group there is a correlation between the roles of "innovator" and "coordinator", that is, most respondents who identify with constant change, creative thinking and management of transitions in the organization, also identify themselves with project management, work planning and managing different situations at the same time. This cluster demonstrates that managers who consider themselves creative and receptive to change, also consider that they have good skills in planning and executing multitasks and have a very important and dynamic profile.

\subsection{Factor Analysis}

The exploratory factor analysis was performed with the statistical software IBM SPSS V.24. This analysis aimed to identify the grouping of variables through their factor load - formation of factors. Thus, each factor generated is the representation of a group of variables that are statistically identified, therefore, it is the synthesis of what each group of variables can represent (Malhotra, 2012; Hair Jr. et al., 2014). The method of factor analysis was chosen by means of extraction by Principal Component Analysis, along with the Equamax rotation method with Kaiser Normalization. These two statistical methods allowed the identification of four different factors from the data listed for the composition of the factors, which considered the variables that had a factor load above 0.4 (Malhotra, 2012; Hair Jr. 
et al., 2014). The variables selected to compose the factors can be seen in Table 3, where the results of the data processing are, with the labels of the variables followed by their respective factor load.

Table 3. Factor analysis

\begin{tabular}{|c|c|c|c|c|c|c|c|}
\hline Factor 1 & & Factor 2 & & Factor 3 & & Factor 4 & \\
\hline Negotiator & 0,705 & $\begin{array}{l}\text { Strategic } \\
\text { Planning }\end{array}$ & 0,688 & $\begin{array}{l}\text { Improvement of Products } \\
\text { and Services }\end{array}$ & 0,764 & Management Course & 0,753 \\
\hline Producer & 0,648 & Monitor & 0,623 & Updating & 0,735 & Financing & 0,724 \\
\hline Mentor & 0,631 & Coordinator & 0,573 & Differential & 0,641 & Labor Capital & 0,546 \\
\hline Innovator & 0,622 & Director & 0,568 & Workforce Training & 0,452 & & \\
\hline Facilitator & 0,610 & Cash Control & 0,519 & & & & \\
\hline Director & 0,448 & Facilitator & 0,457 & & & & \\
\hline Monitor & 0,439 & & & & & & \\
\hline Differential & 0,430 & & & & & & \\
\hline
\end{tabular}

Source: Research data

The first factor (Factor 1) includes the roles of negotiator, producer, mentor, innovator, facilitator, director, monitor and the dimension of differential in relation to the competition. These are characteristics that arise from this set of variables and are possible to describe this factor as a dimension that encompasses a strong base of power, focus on work and the work environment, attention to employees and communication, coexistence and change management, teamwork and management conflicts, work through goals and planning, performance management, so it is believed that this set of characteristics is different from competitors. Factor 1 demonstrates that the respondents that make up this group have a focus on the business itself, on their organization and performance, in addition to having dynamism and making decisions based on the market, the individual capabilities of their employees and the collective capacity of their work teams. The participants in this factor group focus on organizational efficiency as something that can differentiate their business from the others, so that the managerial skills of this factor are based on "Focus, Production and Development".

The second factor (Factor 2) includes the variables "strategic planning, monitor, coordinator, director, cash flow control and facilitator". It is possible to check in the items of this set of variables the following characteristics of the managers: emphasis on the actions of strategic planning, monitoring and management of individual and collective performance, in the management of activities, goals and projects, in the work based on goals and pre-defined, in the attention to the control of finances and cash flow, in the teamwork and in the internal conflict management. Thus, it is understood that this factor is based on the planning and control of activities, therefore, managerial competencies have a focus on "Planning and Control".

The grouping of the variables of the third factor (Factor 3) consists of the "improvement of products and services, updating in relation to the market, differential in relation to the competition and training of labor. These variables take care with the constant improvement of products and services as a means to attract customers, in addition to confronting their activities with those of the competition, to seek to differentiate themselves from other businesses in the segment, as well as investing in the training of labor to offer better products and services. This factor includes characteristics of market monitoring in environments of intense competition, with a focus on managerial skills supported by "Market Differentiation".

The last factor (Factor 4) groups the variables "courses for improving management, acquisition of loans and financing and training of labor". Thus, as shown in the map of clusters, this factor presents a group composed of managers who are concerned with their professional improvement and believe that they should encourage their employees to participate in training programs. In addition, they are managers who have the characteristic of daring in the acquisition of loans and financing, as they believe that these mechanisms have the potential to develop their business, with a focus on managerial skills of "Training and Investments". 
Therefore, this research identifies the factors that make up the dimensions of managerial competencies and distinguishes the groups of respondents according to statistical similarities. There are the managerial competencies dimensions "focus, production and development", which encompasses the group with a vision focused on the interior of the company and at work; managerial competencies "planning and control", with an emphasis on plans and their execution, especially on the resources needed to carry them out; there are also the managerial skills of "market differentiation", marked by the focus on high competition and on offering consumers something that differentiates them from the competition; and, finally, the managerial competencies "training and investments", which represent the group of managers concerned with investing in labor and in the acquisition of financial resources for investments in the organization. These four factors represent the synthesis of the empirical data of this research, which, in turn, synthesizes the essential managerial skills for the management of micro and small companies, according to the perception of the managers participating in the sample.

Yet, these essential managerial skills, if applied to the management of micro and small companies, positively impact business survival. The focus on production and development, planning and control, market differentiation, training and investments, summarize the set of managerial skills that managers of micro and small companies must have to minimize the chances of business mortality and increase the chances of survival and growth when these companies are located in a developing geographic environment, such as the city of Porto Velho, located in the northern region of Brazil.

\section{Discussion}

This work aimed to identify the dimensions that make up the managerial skills essential to the management of micro and small companies. The identification of the dimensions that make up the essential managerial competences was carried out by means of a diagnosis of the empirical reality in companies located in the city of Porto Velho, State of Rondônia - Brazil. Although the management literature used by this study already has a large volume of relevant information, this work innovated by identifying a new practice to test the concepts consolidated in the literature. In addition, the work incorporated data from management reports (SEBRAE, 2016), which comes from the practical environment, to expand the way of applying the theoretical elements presented in the theory, whose purpose was to test new practices and managerial contexts, in a different way from analyzes in other studies and environments. These contributions are, without a doubt, scientific qualities of this research, especially with regard to the impacts of management skills on the survival of this type of companies - micro and small businesses.

As an answer to the research question proposed by this work, the analyzes performed identify that the skills needed by managers are related to production and development, where the manager must keep an eye on the maintenance of the business, through capital turnover, with sales shorter term and long-term purchases, in addition to carrying out production activities efficiently. Business planning and control skills are also essential. The activity of planning has long been listed as one of the primary factors in the execution of any business, and this planning must, necessarily, be associated with some type of control for it to be carried out satisfactorily. This managerial competence presents little more than the obvious for people who are involved in the universe of business, but it may seem a light at the end of the tunnel for companies that face harsh realities such as those experienced by micro and small companies in Brazil, especially in the northern region, site of this study.

Another set of managerial competencies fundamental to business survival in the scope of this study is market differentiation. Even in a business environment in which the level of formal education is precarious, the managers participating in the survey highlight marketing actions as essential to the survival of their businesses. This is because the change in products and services is noticeable on several levels, and even a manager who has not studied marketing, can visualize the daily changes in the business scenario and in the needs and demands of his/her customers. It is latent that the managers of these small businesses need to be attentive to the market when making decisions in their businesses, as each different element will count in the client's decision.

The last set of essential managerial skills for micro and small companies identified by this study is "training and investments". The managers participating in the research highlight, despite the little instruction observed in the indicators, the concern with the level of qualification and the availability of financial resources, both essential for a business to last and prosper in any economic scenario, especially in the precarious ones as is the case. Thus, the managerial competencies presented as essential for the survival of companies in the studied environment demonstrate an important reality to be considered in the scope of administration, as the sample of this research reveals that the companies that survive in this type of market, only succeed because they are attentive to what which is essential and elementary, but the themes of administration, finance and marketing are not part of the universe of these micro and small entrepreneurs, so the study should provoke the reflection of business professors, public 
administrators, managers of development institutions and qualification for this type of business, as subjects studied in the academy generally do not achieve this observed reality.

As the main theoretical contribution, this research presents the four dimensions of managerial competences in micro and small companies. The managerial contribution is about the application of these managerial skills in the practice of managers of micro and small companies in the city of Porto Velho - Rondônia, through qualification courses after conducting the research. The factors interpreted as a synthesis of the managerial competences of Quinn et. al. (2003) added to the essential elements for business survival pointed out by SEBRAE (2016), it presents a new list of skills, synthesized and explained, that can be useful for managers of micro and small companies that exist in an environment similar to the one studied, as well as the researcher who seeks to understand organizations in these contexts. As suggestions for future research, the authors believe that these four factors can be applied in research with micro and small companies in other geographic regions, in order to observe the differences between the priorities of managers from different locations. In addition, the impact of these managerial skills on the results and competitiveness of organizations can be measured.

\section{Conclusions and Implications of the Research}

This article sought to understand the factors related to managerial competencies that are closely related to the success and failure of the enterprises, so that, once their relationship with the determining factors of business mortality is understood, it is possible to develop mechanisms to minimize the death of micro and small companies, especially those located in geographic areas with a high density of these problems.

It was possible to observe that there are groups of competences that stand out in the "essential" item, proving to be truly indispensable, not only for the development of the business, but moreover, for its survival. Although the literature on essential skills classifies them all as indispensable, this research was able to bring a new discussion on the subject, by filtering these skills, extracting their essence from the practical world in terms of applicability and necessity.

It is recognized the importance of all the competences discussed as indispensable for the good performance of the business, and because some of them proved to be more important, the term "essentials" should not be considered trivialized. The fact that some of them proved to be less relevant in the observed practical environment, occurs because this research focused specifically on business survival, and this survival alone is not enough to guarantee good economic and social development. Therefore, all the competencies discussed in this article have a high degree of importance.

It is expected that the results of this research will contribute to creating possibilities around improvements in the management policies and practices of the companies involved, thus avoiding the risk of solubility. That is, once there is a diagnosis of what are the primary factors for business survival, it is possible to focus on these items when developing development plans for small businesses.

The main implication of this article, therefore, is to bring to the light of managerial sciences the set of truly essential skills in scenarios where there is a high degree of business mortality, and so this knowledge can allow the desired improvements to be applied, in order to avoid the bankruptcy of companies. This article contributes with useful information for practical improvement actions, at the same time that it adds value to theoretical discussions, and promotes a small advance in the study of essential competences. As a suggestion for future research, we recommend that new surveys be carried out on the practical application of essential skills in the management of small companies, in order to identify in a practical way the contributions of each one of them and to deepen the studies on their potential.

\section{Acknowledgements}

We would like to thank all the managers of the micro and small companies that participated as respondents in this research and also the undergraduate students of the Bachelor of Science in Business Administration at Fundação Federal University of Rondônia who worked on data collection. To all of you, our gratitude.

\section{References}

Albuquerque, A. A. De., Gonçalves-Júnior, É. V. G., Lacerda, M. C., \& Morais, F. R. De. (2019). When Network Capabilities Influence Business Survival? A Review. European Journal of Scientific Research, 153(3), 234-249. Retrieved from www.europeanjournalofscientificresearch.com/issues/PDF/EJSR_153_3_02.pdf 
Araújo, F. E. De., Morais, F. R. De., \& De Souza Pandolfi, E. (2019). A Fábula Dos Mortos-Vivos: Determinantes da Mortalidade Empresarial Presentes em Micro e Pequenas Empresas Ativas. Revista de Empreendedorismo e Gestão de Pequenas Empresas, 8(2), 250-271. https://doi.org/10.14211/regepe.v8i2.763

Barbosa, R. A. P., Silva, E. A. Da., Gonçalves, F. H. L., \& Morais, F. R de. (2020). O Impacto da Educação Empreendedora na Intenção de Empreender: análise dos traços de personalidade. Revista de Empreendedorismo e Gestão de Pequenas Empresas, 9(1), 124-158. https://doi.org/10.14211/regepe.v9i1.1589

Davel, E. P. B., \& Melo, M. C. D. O. L. (2005). Gerência em ação: singularidades e dilemas do trabalho gerencial. FGV Editora.

Eniola, A. A., \& Entebang, H. (2015). SME firm performance-financial innovation and challenges. Procedia-Social and Behavioral Sciences, 195, 334-342. https://doi.org/10.1016/j.sbspro.2015.06.361

Felício, M. J., Parreira, P. M., \& Lopes, A. (2011). Competências de gestão: contributo para a validação de um instrumento. In Conferência-Investigação e Intervenção em Recursos Humanos (No. 3). https://doi.org/10.26537/iirh.v0i3.1871

Ferreira, L. F. F., Oliva, F. L., Santos, S. A. D., Grisi, C. C. D. H., \& Lima, A. C. (2012). Análise quantitativa sobre a mortalidade precoce de micro e pequenas empresas da cidade de São Paulo. Gestão \& Produção, 19(4), 811-823. https://doi.org/10.1590/S0104-530X2012000400011

Freitas, P. F. P. De., \& Odelius, C. C. (2017). Escala de competências gerenciais em grupos de pesquisa. Revista de Administração FACES Journal, 16(4), 46-65. https://doi.org/10.21714/1984-6975FACES2017V16N4ART4134

Galvan, L., \& Villela, R. V. (2014). O cenário do empreendedorismo no Brasil e a atuação dos empreendedores como gestores. Revista da Graduação, 8(2).

Hair, Jr., Joseph, F., et al.. (2014). Multivariate data analysis (7th ed.). Pearson Education Limited.

Hamel, G., \& Prahalad, C. K. (1990). The core competence of the corporation. Harvard Business Review, 68(3), 79-91.

IBGE-Instituto Brasileiro de Geografia e Estatística. (2017). Quantitativo de empresas em Porto Velho RO. [S. l.: s. n.]. Retrieved

from https://cidades.ibge.gov.br/brasil/ro/porto-velho/pesquisa/19/29765?tipo=ranking\&indicador=29761

Kummitha, R. K. R. (2019). Smart cities and entrepreneurship: An agenda for future research. Technological Forecasting and Social Change, 149, 119763. https://doi.org/10.1016/j.techfore.2019.119763

Lara, F. J., \& Salas-Vallina, A. (2017). Managerial competencies, innovation and engagement in SMEs: The mediating role of organisational learning. Journal of Business Research, 79, 152-160. https://doi.org/10.1016/j.jbusres.2017.06.002

Maldonado-Guzman, G., Marin-Aguilar, J. T., \& Pinzon-Castro, S. Y. (2017). Knowledge Management in Mexican Manufacturing Small Business. International Journal of Business Administration, 8(2), 47. https://doi.org/10.5430/ijba.v8n2p47

Malhotra, N. K. (2012). Pesquisa de Marketing-:Uma Orientação Aplicada. Bookman Editora.

Morais, F. R. De., \& Luz, T. R. Da. (2015). Competências Gerenciais em serviços de saúde: um estudo multicasos em hospitais de Belo Horizonte.Divers@!, 8(2). https://doi.org/10.5380/diver.v8i2.45054

Mwobobia, F. M. (2012). Role of business management into the success and survival of small businesses: The case of star learning centre in Botswana. International Journal of Business Administration, 3(1), 93. https://doi.org/10.5430/ijba.v3n1p93

Quinn, R. E. (2003). Becoming a master manager: A competency framework. John Wiley \& Sons Inc.

Quinn, R. E., Faerman, S. R., Thompson, M. P., \& McGrath, M. R. (2003). Becoming a Master Manager: A Competency Approach. Hoboken.

Saunders, M., Lewis, P., \& Thornhill, A. (2012). Research methods for business students. Harlow: Pearson.

SEBRAE. (2016). Estudo Sobre Sobrevivencia Das Empresas No Brasil. Retrieved from http://www.sebrae.com.br/Sebrae/Portal Sebrae/Anexos/sobrevivencia-das-empresas-no-brasil-102016.pdf

Toma, S. G., Grigore, A. M., \& Marinescu, P. (2014). Economic development and entrepreneurship. Procedia Economics and Finance, 8(0), 436-443. https://doi.org/10.1016/S2212-5671(14)00111-7

Walter, A., Auer, M., \& Ritter, T. (2006). The impact of network capabilities and entrepreneurial orientation on university spin-off performance. Journal of Business Venturing, 21(4), 541-567. https://doi.org/10.1016/j.jbusvent.2005.02.005 